\title{
تقويم متعلمي اللغة العربية لغير الناطقين بها \\ في ضوء الكفايات المطلوبة منهم
}

\author{
Maimun Bin Ahmad Alsolamy* \\ Institite of Arabic Language for Non-Native Speakers, Umm Al-Qura University, Saudi Arabia
}

Evaluation of Learners of the Arabic Language for Non-Native Speakers

in Light of the Competencies Required of Them

E-Mail Address

masolamy@uqu.edu.sa

${ }^{*}$ Corresponding Author

\section{Keywords}

Improvement;

teaching Arabic language;

non-native speaker

\begin{abstract}
The evaluation of Arabic language learners to non-native speakers is linked to the competencies required to enable them, and to the goals or competencies specified in advance. Valuation is based on it to see the extent of its realization or not. The study aimed to know the competencies required to enable Arabic language learners to non-native speakers of it, and to methods of evaluating Arabic language learners to non-native speakers in light of it, and the study used the descriptive approach. The study concluded: the goal of teaching Arabic to non-native speakers is to empower learners with linguistic, communication, and cultural competencies, and that evaluating Arabic language learners to non-native speakers is according to the three competencies, and those linguistic activities have a role in evaluation, in developing and developing competencies, and that all kinds of language tests It is part of the evaluation of learners of the Arabic language for non-native speakers and is not the only method of evaluation.
\end{abstract}

\section{المقدمة}

فإن تعلم أي لغة يقتضي معرفة ضمنية بالقواعد التي تحكم نظامها، وبالقواعد التي تحكم استعمالها،

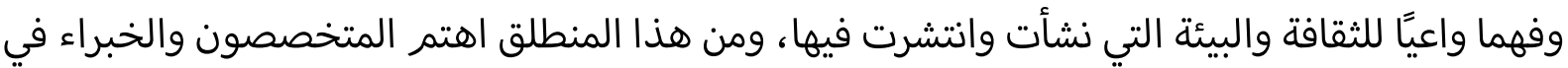
تعليم اللغات بتعليم الكفايات الثلاث (الكفاية اللغوية، والكفاية الاتصالية، والكفاية الثقافية)، ولا تزال بعض معاهد ومراكز تعليم اللغة العربية لغير الناطقين بها تركز على كفاية واحدة وهي الكفاية اللغوية،

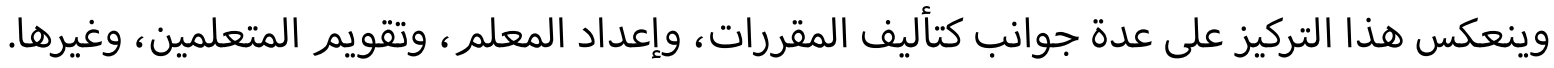

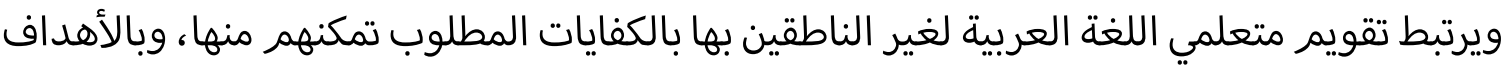

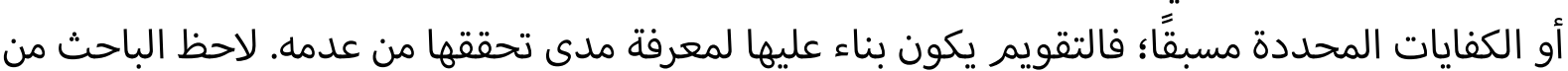


خلال خبرته في تدريس متعلمي اللغة العربية لغير الناطقين بها في أكثر من معهد أن هناك قصورًا في تقويم المتعلمين وفق كفاياتهم، ومن هذا المنطلق فإن مشكلة الدراسة تتركز في الحاجة إلى معرفة واستخدام طرق وأساليب تقويم متعلمي اللغة العربية لغير الناطقين بها في ضوء الكفايات المطلوب تمكنهم منها. وتجيب الدراسة عن السؤالين الآتيين: (ا) ما الكفايات المطلوب تمكن متعلمي اللغة العربية لغير الناطقين بها منها ؟؛ (Y) كيف نقوم متعلمي اللغة العربية لغير الناطقين بها في ضوء هذه الكفايات؟ تهدف الدراسة إلى معرفة الكفايات المطلوب تمكن متعلمي اللغة العربية لغير الناطقين بها منها، وإلى طرق تقويم متعلمي اللغة العربية لغير الناطقين بها في ضوء الكفايات المطلوبة منهم (الكفاية اللغوية، والكفاية التواصلية، والكفاية الثقافية). وتساعد هذه الدراسة المعلمين والمسؤولين بمعاهد ومراكز تعليم اللغة العربية لغير الناطقين بها في تطوير أساليب وطرق التقويم لمتعلمي اللغة العربية لغير الناطقين • ومن أسباب الدراسة: (ا) قلة المتخصصين في ميدان تعليم اللغة العربية لغير الناطقين بها في المعاهد؛ (r) ممارسة التعليم عن اللغة لا تعليم اللغة، وبالتالي يتأثر التقويم بهذين العنصين مئصرين فيصبح تقويماً لمعلوماتهم أو معارفهم عن اللغة وليس تقويماً لمهاراتهم في اللغة وفق الكفايات اللغوية والاتصالية الثقافية المطلوبة منهم؛ () قلة البحوث والدراسات في مجال تقويم متعلمي اللغة العربية لغير الناطقين وفق كفاياتهم.

دراسات اهتمت بتقويم متعلمي اللغة العربية لغير الناطقين بها، منها: دراسة نادية مصطفى العساف وختام محمد الوزان، "أسس تصميم اختبارات اللغة العربية للناطقين بغيرها" (عا•r). وهدفت

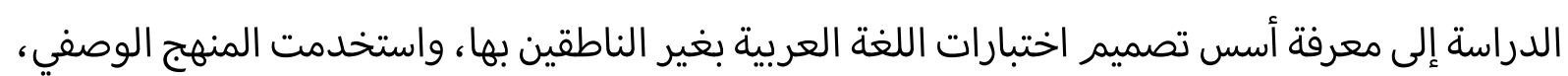
وتوصلت إلى أن اتباع نظام وأسس في تصميم الاختبار يجعله ذا مصداقية عالية من حيث المحتوى، وإلى إن إعداد الاختبار يستدعي التمسك بأهداف المادة، وتحديد نوعية الأسئلة التي تناسب المادة، مع مراعاع لظعاة مدة الاختبار، وترتيب الأسئلة من السهل إلى الصعب، وتبادئل وتوافر جميع صفات الاختبار الجيد من صدق

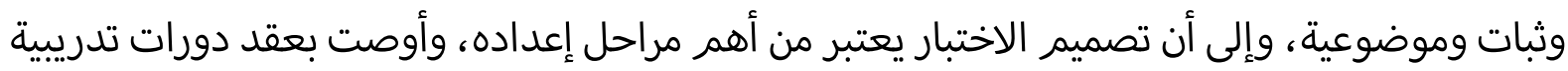
للمعلمين حول كيفية إعداد الاختبارات السليمة للطلاب، ومراعاة مستويات الطلبة وخبراتهم السابقة عند

الإعداد للاختبارات، و إجراء دراسات تشمل طرق تقويم قدرات الطلبة (al-'Assāf \& al-Wazān, 2014).

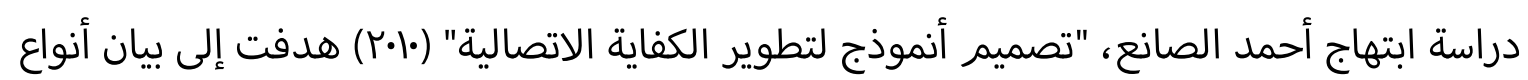
الكفاية، وكيف يسهم المعلم في تطوير كفايات المتعلمين التواصلية، وكيف يتم تطبيق الكفاية التواصلية في مواقف لغوية مناسبة، وقد استخدمت المنهج الوصفي التحليلي، وأوصت بضرورة إجراء المزيد من الدراسات المشابهة (al-Ṣāni‘, 2010). أما دراسة حسن بن محمد مداس الشمراني، "اختبار العربية المعياري: تجربة الجامعة السعودية الإلكترونية في قياس الكفاية اللغوية لمتعلمي اللغة العربية لغير الناطقين بها" (7/(r)، هدفت إلى التعريف باختبار العربية المعياري وأهدافه، والأطر والمعايير التي بني عليها، والأفراد والجهات التي تستفيد منه، ومراكز انعقاده، والتعرف إلى اختبار العربية المعياري من حيث مكوناته

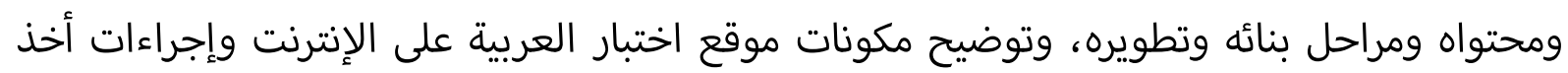


الاختبارات. وقد أوضحت نتائج الدراسة أن مركز الاختبارات في الجامعة قد اطلع على أطر وتجارب عالمية عدة، واستأنس بتجارب اختبارية كثيرة، إلا أنه تبنى الإطار الأوروبي المرجعي المشترك للغات (CEFR)

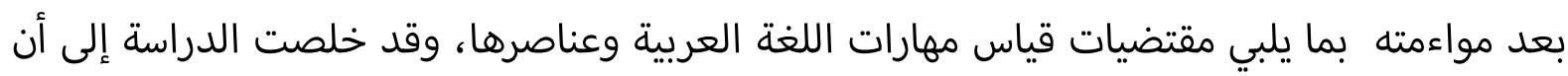
اختبار العربية المعياري، إلى جانب خدمة اللغة العربية ونشرها وقياس القدرة اللغوية لدى غير الناطقين بالعربية، يهدف إلى مساعدة مؤسسات التعليم العالي وجهات العمل ذات العلاقة، وذلك في اتخاذ القرارات المناسبة (al-Shamrānī, 2016).

ويختلف هذا البحث عن الدراسات السابقة بأنه يقدم طرق لتقويم متعلمي اللغة العربية لغير الناطقين بها في ضوء المفهوم الشامل للتقويم الذي يشمل الأنشطة ولا يقتصر على الاختبارات فقط وفي ضوء الكفايات الثلاث المطلوب تمكن متعلمي اللغة العربية لغير الناطقين بها منها، اللغوية والثقافية

والاتصالية.

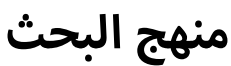

تستخدم الدراسة المنهج الوصفي، وهو كل منهج يرتبط بظاهرة معاصرة بقصد وصفها وتفسيرها

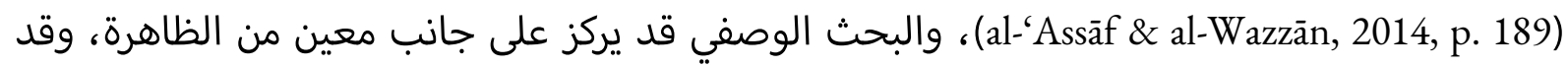
يدرسها من جوانبها المتعددة ('Abd Allāh, 2006, p. 68).

\section{نتائج البحث والمناقشة}

أ. الكفايات المطلوب تمكن متعلمي اللغة العربية لغير الناطقين بها يذكر اللقاني أن الكفايات "تصف الحد الأدنى للأداء، وعندما يصل أي فرد إلى هذا الحد فإن هذا يعني أن

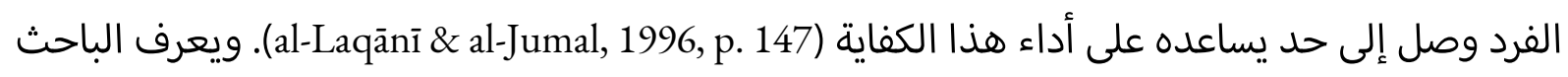
الكفايات إجرائيا بأنها: الحد الأدنى من تمكن متعلمي اللغة العربية لغير الناطقين بها لمهارات اللغة العربية، وحسن استخدامها في بيئة عربية.

ا. الكفاية اللغوية

وتمثل أساس وعمق الكفايات الثلاث، وتعني في مجال تعليم اللغة العربية لغير الناطقين بها تزويد المتعلمين بالمهارات اللغوية التي تجعلهم قادرين على فهم طبيعة اللغة والقواعد التي تضبطها، والنظام الذي يحكم ظواهرها، والخصائص التي تتميز بها مكوناتها أصواتًا ومفردات وتراكيب ومفاهيم

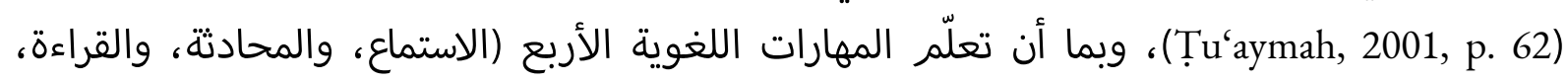
والكتابة) هو الهدف الرئيس من تعلّم اللغة، وما لهذه المهارات أهمية ومكانة خاصة في تعليم اللغات الثانية فقد حدد المتخصصون في هذا الميدان كفايات خاصة لتعليم كل مهارة من هذه المهارات الأربع. 
أ) عفايات مهارات الاستماع

(ا) تعرف الأصوات العربية وتمييز ما بينها من اختلافات صوتية ذات دلالة عندما تستخدم في الحديث العادي وبنطق سليم؛ (r) تعرف الحركات الطويلة و الحركات القصيرة والتمييز بينها؛ (ّ) التمييز بين الأصوات العربية المتجاورة في النطق والمتشابهة في الصوت مع التركيز على الأصوات التي لا توجد إلا

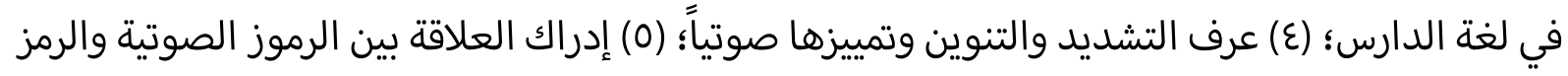
المكتوبة؛ (7) الاستماع إلى اللغة العربية دون أن تعوق ذلك قواعد تنظيم المعنى؛ (V) سماع الكلمات

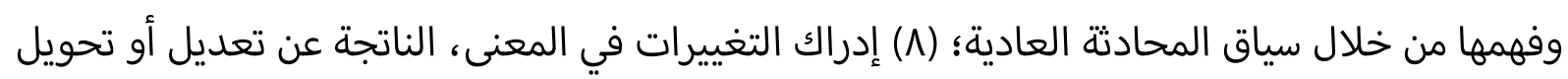
في بنية الكلمة (المعنى الاشتقاقي)؛ (9) فهم كيفية استخدام الصيغ المستعملة في اللغة من حيث ترتيب الكلمات تعبيراً عن المعنى؛ (•() فهم استخدام صيغ اللغة العربية من حيث التذكير والتأنيث؛ (II) إدراك أن المعنى الدلالي للكلمة العربية قد يختلف عن ذلك الذي تعطيه أقرب كلمة في لغة الدارس الأمر (זا) إدراك نوع الانفعال الذي يسود الحديث والاستجابة له (النبر والتنغيم)؛ (سا) فهم المعاني المختلفة المتصلة بالجوانب المختلفة للثقافة والعربة والإسلامية؛ (عا) الاستفادة من تحقيق كل هذه الجوانب في al-Nāqah, 1985, p. ) متابعة الاستماع إلى اللغة العربية الفصحى في المواقف اليومية التي تستخدم فيها

ب) كفاية مهارة المحادثة (ا) أن ينطق المتعلم أصوات اللغة العربية، وأن يؤدي أنواع النبر والتنغيم المختلفة بطريف مقبولة من

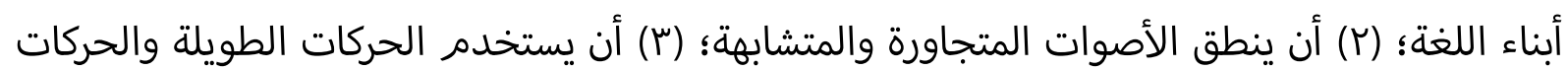
القصيرة؛ (ع) أن يعبر عن أفكاره مستخدماً النظام الصحيح لتركيب الكلمة في العربية خاصة في لغة إنة الكلام الفصحى؛ (0) أن يكتسب ثروة لفظية كلامية مناسبة لعمره وحاجاته وأدواره وخبراته وأن يستخدم هذه الثروة في عمليات اتصال عصرية؛ (7) أن يستخدم بعض أشكال الثقافة العربية والإسلامية المناسبة لعمره ومستواه الثقافي وطبيعة عمله، وأن يكتسب بعض المعلئ المعلومات الأساسية عن التراث العربي الإسلامي؛ (V) أن يعبر عن نفسه تعبيراً واضحاً ومفهوماً في مواقف الحديث البسيطة؛ (N) أن يفكر باللغة العربية ويتحدث بها بشكل متصل ومترابط لفترات زمنية مقبولة (al-Nāqah, 1985, p. 255-256).

\section{ج) كفاية مهارة القراءة}

(ا) أن يربط بين الرموز المكتوبة بالأصوات التي تعبر عنها في اللغة العربية؛ (؟) أن يقرأ نصاً ما قراءة

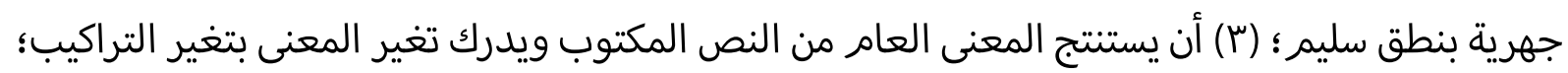

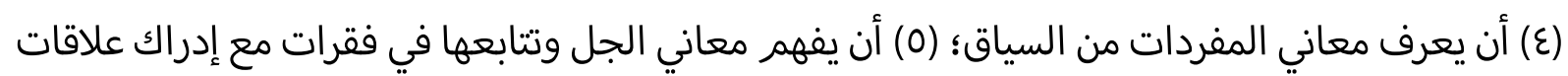
المعاني التي تربط بينها؛ (7) أن يقرأ بفهم وانطلاق دون أن يعوقه عن ذلك التفكير في قواعد اللغة؛ (V)

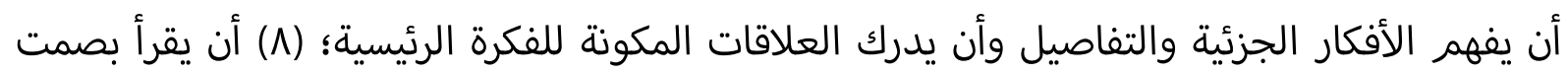




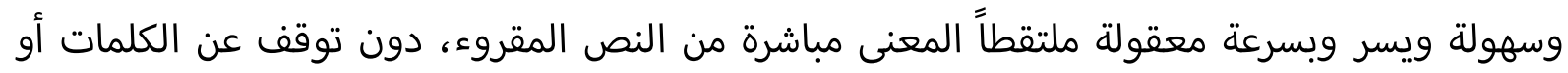

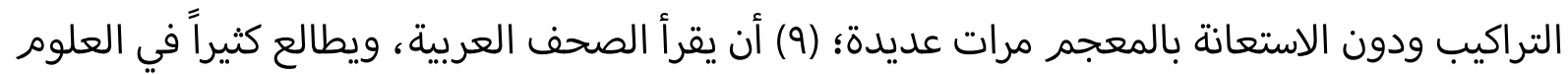
والآداب البسيطة والأحداث الجارية مع لإدراك الوقائع وتحليل المعاني وتحديد النتائج ونقدها وربط القراءة الواسعة بالثقافة العربية الإسلامية (al-Nāqah, 1985, p. 258).

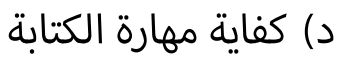
(ا) أن يكتب الحروف العربية ويدرك العلاقة بين شكل الحرف وصوته؛ (r) أن يكتب الكلمات العربية

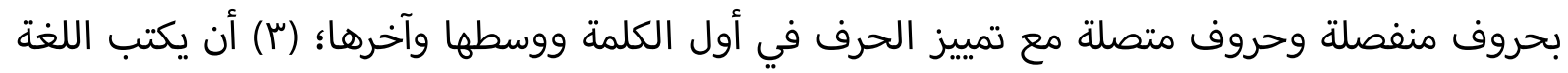

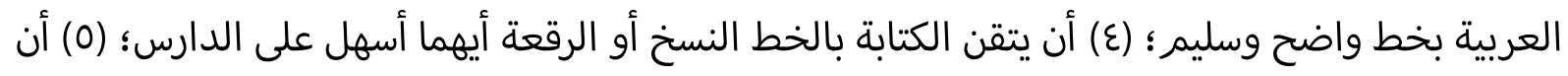

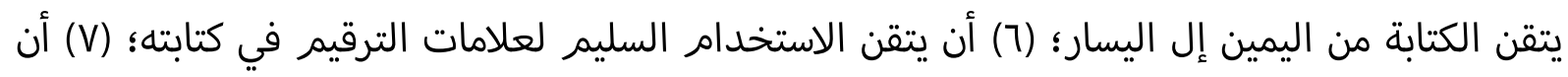

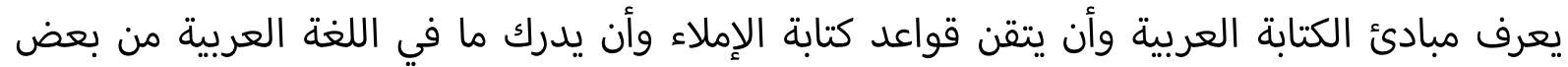

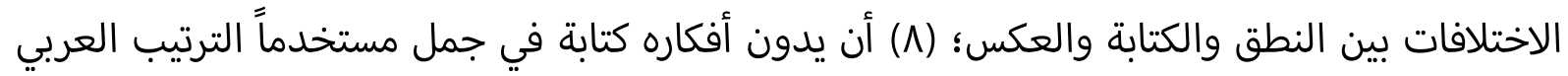

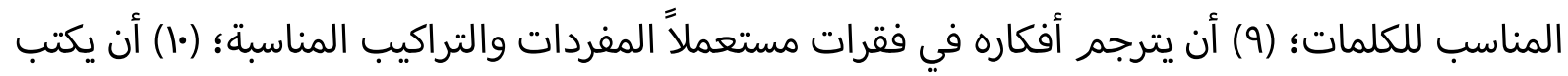
بسرعة مقبولة وبشكل سليم معبراً عن نفسه في سهولة ويسر؛ (II) أن يقرأ الدارس اللغة العرات العربية من اليمين إلى الشمال بشكل سهل ومريح (al-Nāqah, 1985, p. 259).

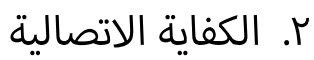
وتعني في مجال تعليم اللغة العربية لغير الناطقين بها تزويد الدارسين بالمهارات اللغوية المناسبة التي

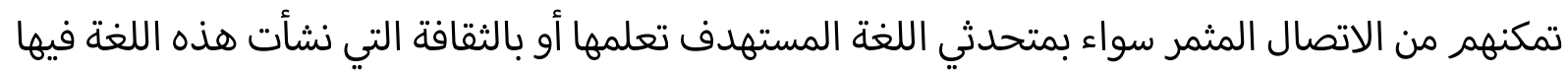
.(Ṭ'aymah, 2001, p. 63)

أ) مجالات الاتصال اللغوي

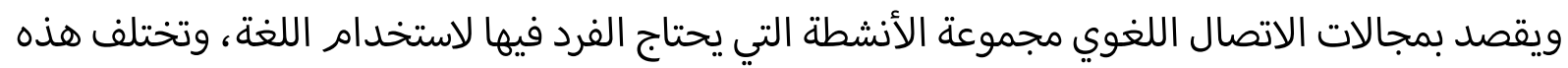

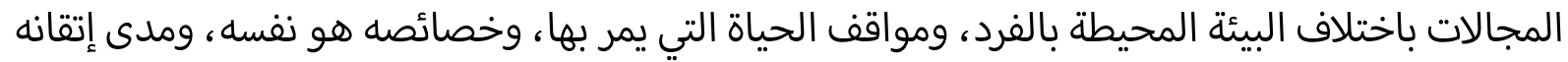

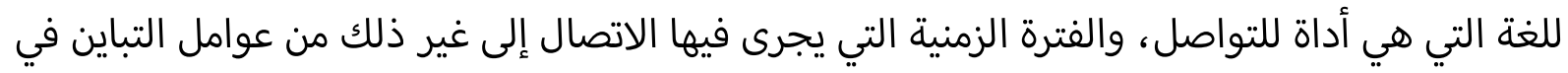

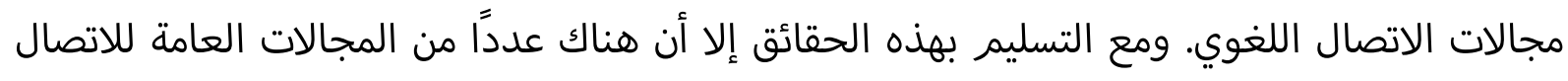

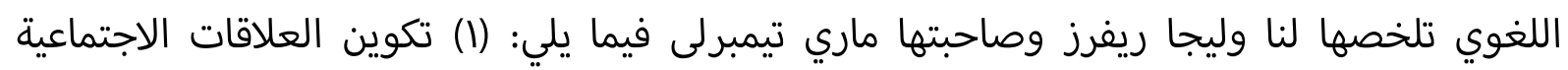

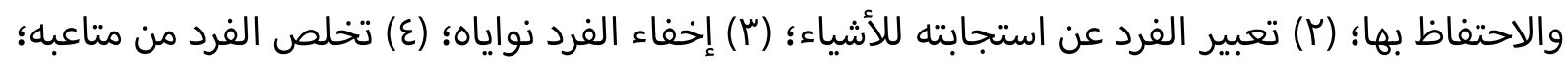
(0) طلب المعلومات وإعطاؤها؛ (7) تعلم طريقة عمل الأشياء أو تعليمها للآخرين؛ (V) المحادثة عبر الإداء

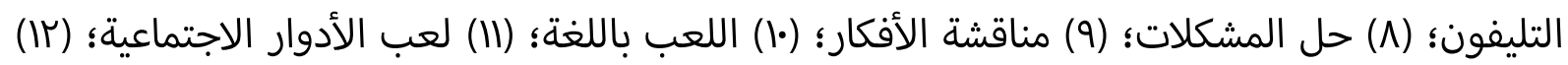


الترويح عن الآخرين؛ (ّا) تحقيق الفرد لإنجازاته؛ (عا) المشاركة في التسلية وإزجاء الفراغ؛ (10) ولكل

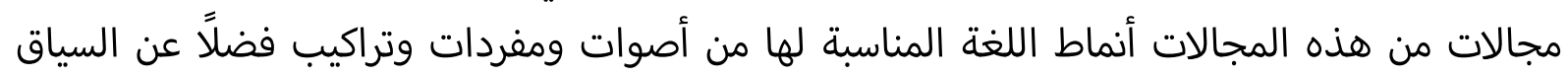
الثقافي المحيط بها (T) (T'u'aymah, 2001, p. 63).

ب) خصائص تدريس اللغة الاتصالي (ا) تركز أهداف التدريس على جميع أجزاء الكفاية الاتصالية ولا تقتصر على الكفاية النحوية أو اللغوية فقط؛ (r) ليس الشكل - البنية - هو الإطار الرئيسي لتنظيم وتسلسل دروس اللغة؛ (ّ) تعتبر الدقة اللغوية أمرًا ثانويًا بالنسبة لإيصال الرسالة الاتصالية، وقد تأخذ الطلاقة أهمية أكبر من الدقة، ويكمن المعيار النهائي للنجاح الاتصالي في الإرسال والاستقبال الحقيقيين للمعاني المطلوبة؛ (ع) يجب على

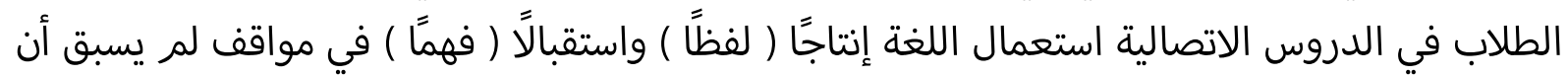
عرفوا أو تدربوا عليها (Brown, 1994, p. 360).

س. الكفاية الثقافية تحتل الثقافة مكانة هامة في تعليم اللغات الأجنبية وتعُلمها ، وتعتبر مكونًا أساسيًا ومكملا مهمًا لمحتوى المواد التعليمية في هذا الميدان؛ لذلك لا بد أن تندمج العناصر الثقافية للغة المستهدفة اندماجًا كاملا في المادة التعليمية وفي جميع أوجه التعُّلم ووسائله (al-Fawzān, 2011, 59). واللغة هي وعاء الثقافة و لا يمكن أن يتم تعلم لغة أخرى حتى يستوعب أو يفهم الطالب ثقافة اللغة الهدف، بل إن تعلم اللغة يراد به معرفة ثقافة اللغة الهدف فلا يُتصور عزل أي لغة عن ثقافتها في تعليمها. فالثقافة تتخلل وتتغلغل في تعليم اللغة وتعلمها في جميع مراحلها ومستوياتها، وينبغي على

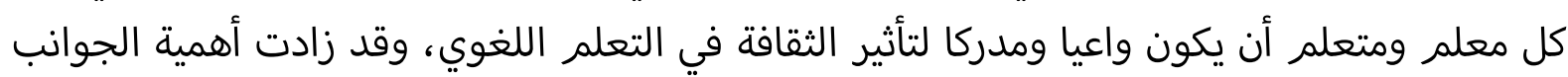
الثقافية مع اتساع دائرة العولمة وزيادة نسب الهجرة، فالكفاية اللغوية رغم أهميتها ومحوريتها، لم تعد الهدف الوحيد من تدريس اللغة الثانية (al-Shuwayrikh, 2016, p. 132). ويرى بعض المختصين أن الثقافة تمثل بُعداً خامساً أو مهارة خامسة ( بالإضافة إلى القراءة، والكتابة، والتحدّث، والاستماع) في تعليم اللُّات الثانية، وتتميز اللغة العربية بأنها لغة للثقافتين: العربية والإسلامية، وكان لنزول القرآن الكريم بها أثر كبير في ارتباطها بالثقافة الإسلامية، ومن بين مظاهر الثقافة العربية والإسلامية المرتبطة باللغة العربية: أسلوب التحية، والزواج، والجنائز، والأعياد، وتناول الطعام والشراب، والحديث إلى الآخرين أو الاستماع إليهم ، وبعض العبادات، وما يرتبط بذلك كله من أقوال قبل

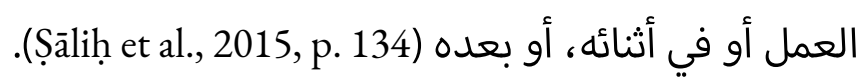
وقد يتساءل بعض الناس عن أسباب تعليم الثقافة بالإضافة إلى تعليم اللغة، ويمكن الإجابة على

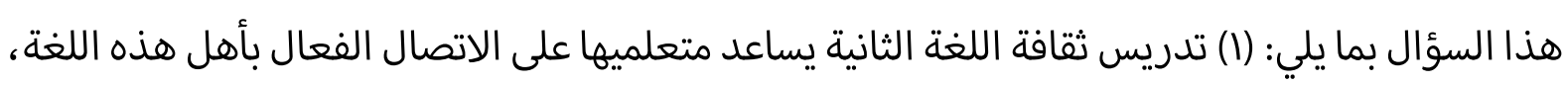
التي يودّون تعلّمها، وتنمية الاتجاه الإيجابي نحوها؛ (r) تدريس ثقافة اللغة الثانية يجعل عملية التدريس 
ممتعة وشائقة، حيث يتعرف الدارسون على أنماط ثقافية جديدة، تختلف عمَّا في ثقافاتهم الأصلية، وهذا

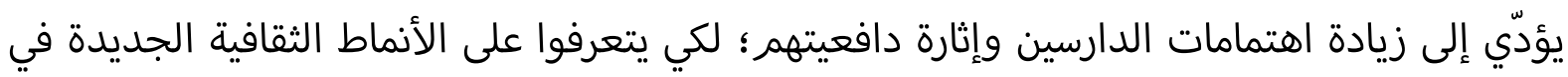

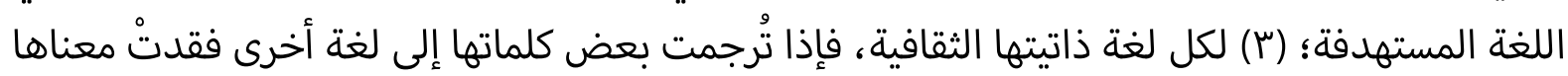

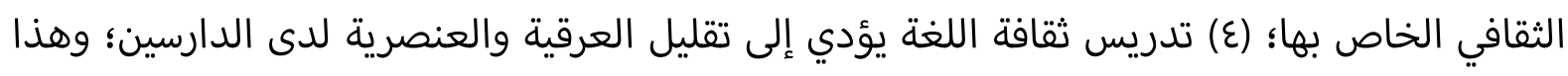

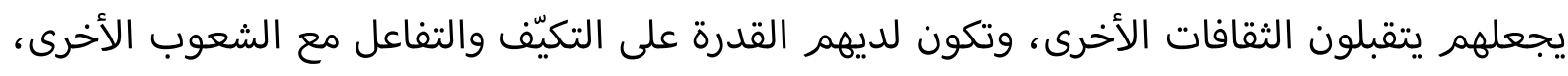

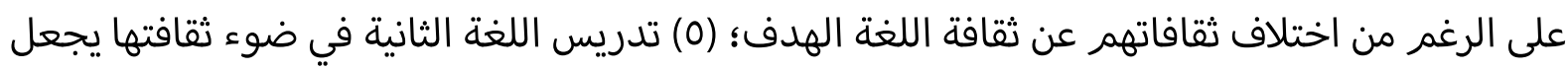

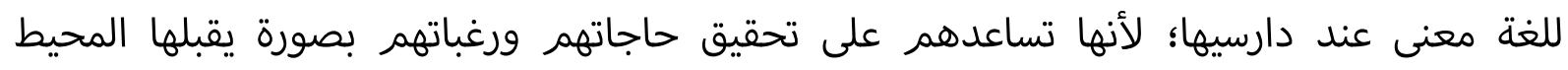

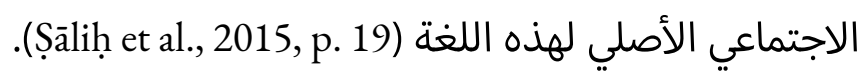

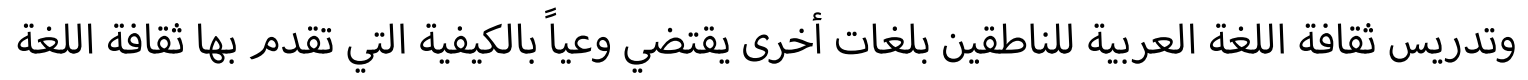

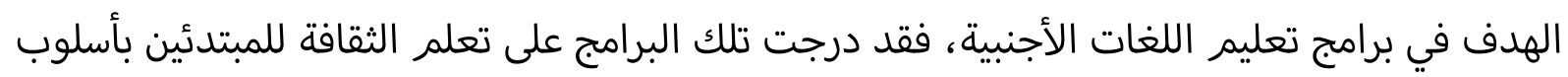

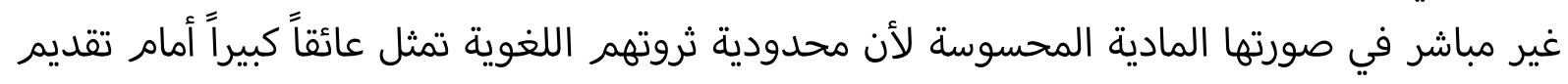
الثقافة لهم بطريقة مباشرة في صورة مقررات دراسية قائمة على بذاتها لكنها متناسقة مع المواد الأخرى ('Abd Allāh, 2007, p. 9) ولقد أثبتت الدراسات أن معظم الدارسين يعلمون أن المعلومات والمعارف الثقافية هدف أساسي

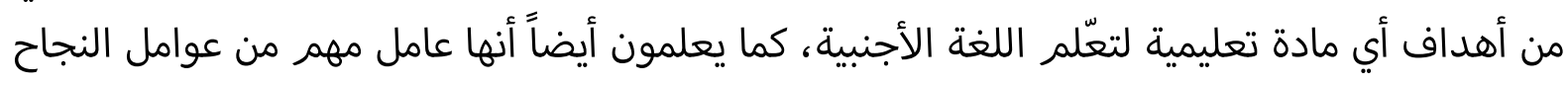

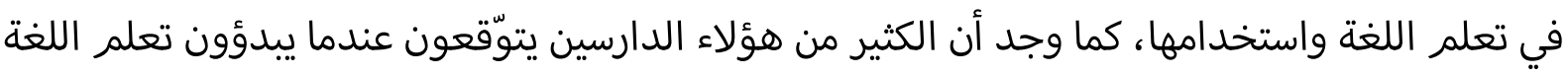

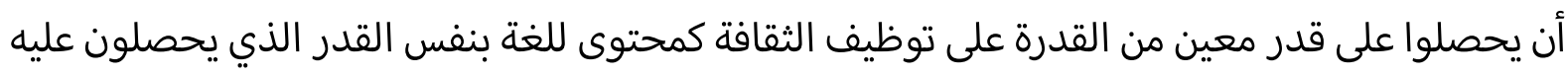

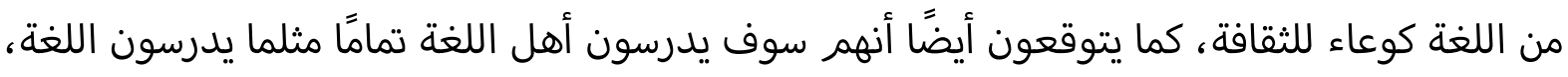

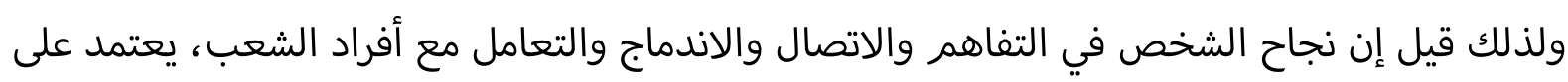
الحصيلة الثقافية التي تعلمها على حد سواء التخص (al-Fawzān, 2011, 59).

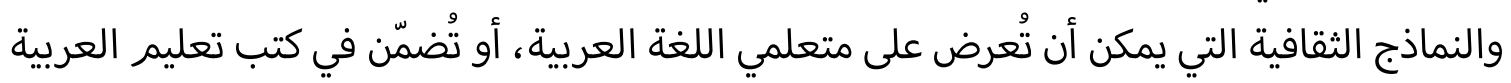

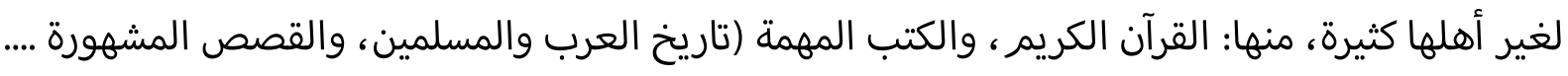

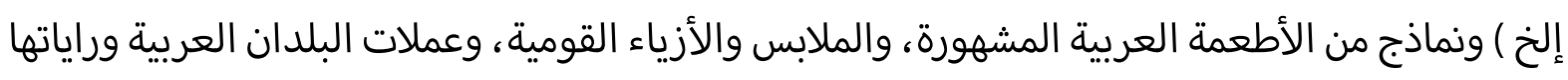

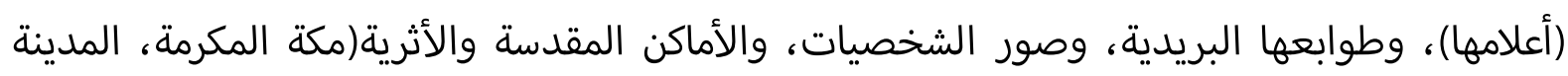

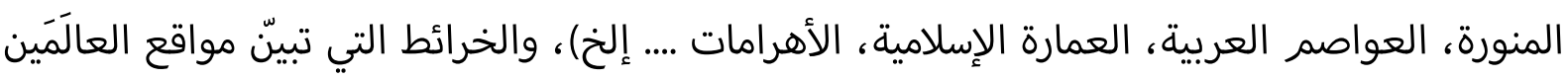

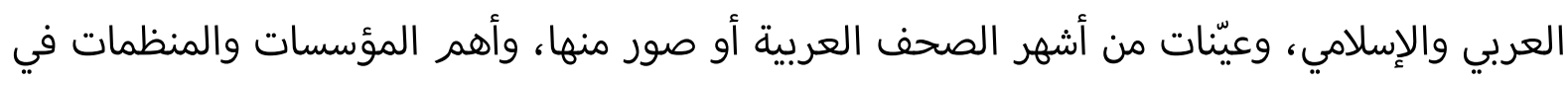

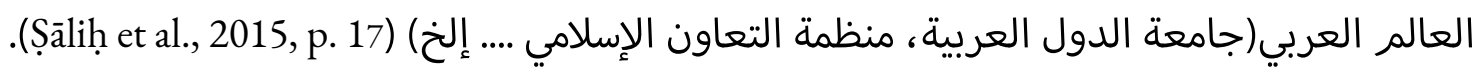


ب.تقويم متعلمي اللغة العربية لغير الناطقين بها في ضوء الكفايات اللغوية والاتصالية والثقافية ا. التقويم عرف التقويم بأنه "عملية جمع المعلومات من مصادر متعددة ومتنوعة ومناقشتها، وذلك لتطوير إدراك معمّق لما يعرفه الطلاب وما يفهمونه، وماذا بإمكانهم فعله بالمعارف التي اكتسبوها نتيجة لخبراتهم التعليمية، وتصل عملية التقويم مداها الأقصى عندما تستخدم نتائج التقويم لاحقاً لتحسين عملية التعلّم. وإذا كان لفظ تقويم أشمل من لفظ تقييم ، وأوسع منه دلالة، فهو أولى منه بالاستعمال في هذا المجال؛ لأن عملية التقويم تبدأ من تقدير الشيء المراد تقويمه تقديرًا كمًا أو كيفيًا، ثم الحكم عليه أليه تمهيدًا لاتخاذ قرار بشأنه من إقرار أو حذف أو تعديل (al-'Aṣilīi, 2001, p. 419). ويعرف الباحث التقويم إجرائيًا بأنه مجموعة الإجراءات التي يقوم بها معلم اللغة العربية لغير الناطقين بها لمعرفة مدى تمكن الطالب من الكفايات اللغوية، والاتصالية، والثقافية , ولرفع مستواه فيها. يساعد التقويم في مجال تعليم العربية كلغة ثانية، في تحقيق ما يلي: (ا) تحديد مستوى الطلاب قبل البدء في البرنامج حتى يمكن وضعهم في المستوى اللغوي المناسب؛ (r) مساعدة الطلاب على اختيار البرنامج المناسب لهم ، وتمكينهم من التوجيه الذاتي المستمر في ضوء ما يعرفونه عن مستواهم اللغوي

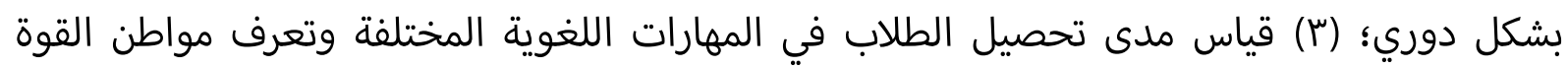
والضعف عندهم فنزيد من الأولى ونعالج الأخرى؛ (ع) تطوير المنهج؛ إذ أن التقويم المستمر من شأنه أن يوقفنا على مواطن السهولة والصعوبة في المنهج، كما يعرفنا بأنسب الطرق لتقديم المعلومات؛ (0) تحفيز الطلاب والمعلمين على مواصلة العمل، ولا شك أن وقوف الإنسان على نتيجة جهده بصفة مستمرة

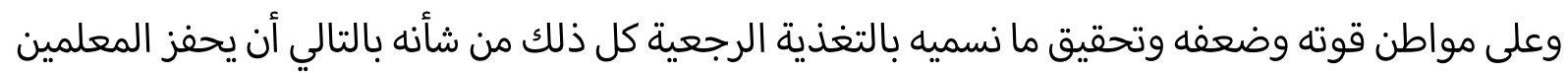

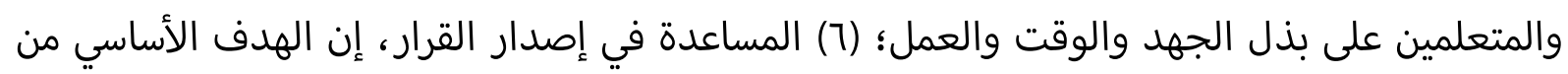
التقويم هو تحسين العملية التعليمية وتمكينها من تحقيق أهدافها، وذلك حتى يمكن إصدار قرار بشأنها،

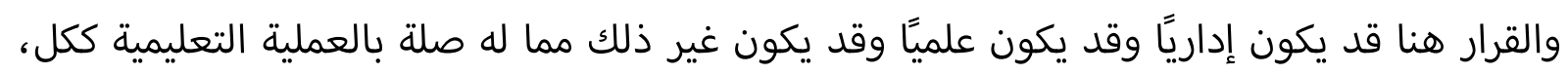
والتقويم بذلك يساعدنا على اتخاذ القرار؛ (V) توعية الجمهور بقيمة البرنامج و تشجيعهم على الانضمام

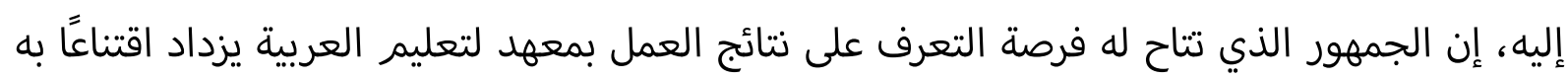

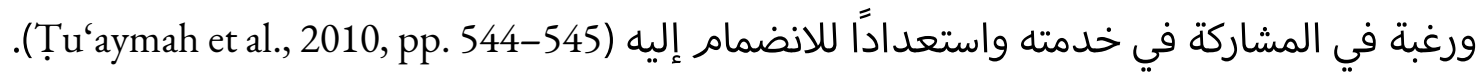

أ) أنواع التقويم ينقسم التقويم إلى (ا) التقويم التصنيفي، ويهدف إل تصنيف المتعلمين وتوزيعهم على المستويات المناسبة لهم؛ (r) التقويم البنائي التكويني، وهو تقويم مستمر يصاحب عملية تعلّم/تعليم الوحدة الدراسية، ويهدف إلى تحديد مدى تقدم المتعلمين نحو إتقان مهارات اللغة وتوظيف عناصرها؛ (ّ) التقويم الختامي أو التجميعي أو النهائي. ويتم بعد الانتهاء من تدريس الوحدات الدراسية، ويهدف إلى إلى 
إعطاء مؤشرات دقيقة عن مدى إتقان المتعلم الكفايات الأساسية المحددة مسبقاً، وتمتلك نتائج التقويم النهائي قوة التأثير ، وإمكانية التعميم (Bānāiimah et al., 1436 H, p. 152).

$$
\text { ب) مرتكزات عملية التقويم }
$$

(ا) ارتباط التقويم بالكفايات التي يسعى المنهج إلى تمكن المتعلم منها؛ (؟) شمول عملية التقويم : تقويم

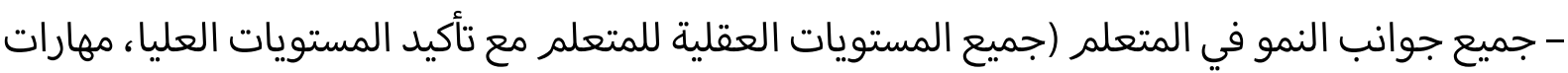

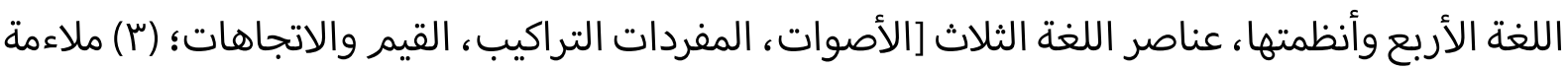

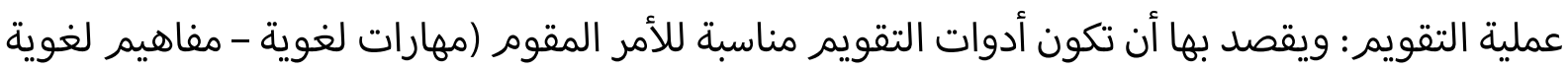
- قيم واتجاهات - عناصر لغوية)؛ (ع) استمرار عملية التقويم: حيث تتم عملية التقويم بطريقة مستمرة،

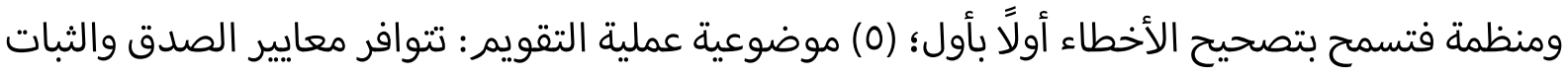
والتوازن والموضوعية في أدوات التقويم المستخدمة (B. (Bānāiimah et al., 1436 H, p. 151).

$$
\text { r. تقويم الكفايات عبر الأنشطة وطرقه }
$$

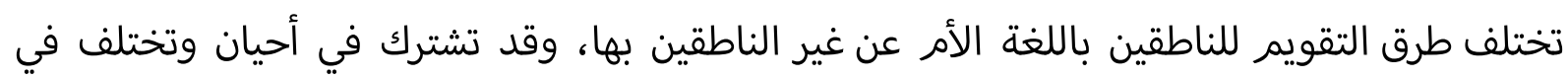
أخرى، ويتبين هذا بالنظر إلى منظومة الكفايات والمهارات المراد تمكين الدارسين منها.

$$
\text { أ) التقييم الذاتي }
$$

يقوم التقييم الذاتي بدور حيوي في مراقبة مدى تقدم الطالب في البرنامج الذي يدرسه فهو يشير

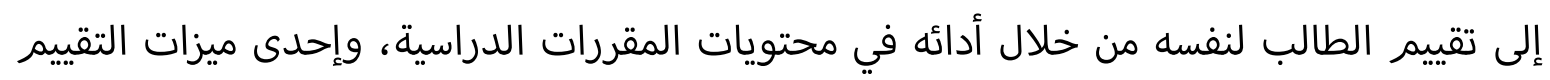

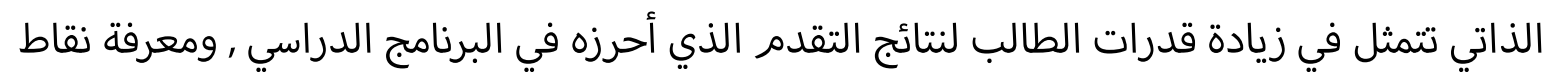

قوته وضعفه (ذئ (Lloyd et al., 2008, p. 190).

ب) تقييم ملف نشاط الطالب ملف نشاط الطالب يتمثل في نماذج مختارة من الأداء، يقوم بجمع كل من الطاط الطالب والمعلم لعينات

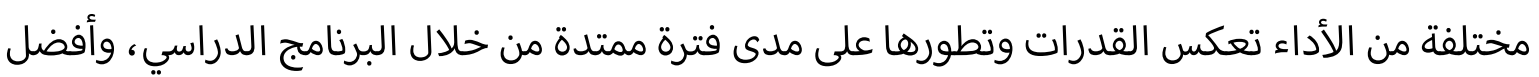

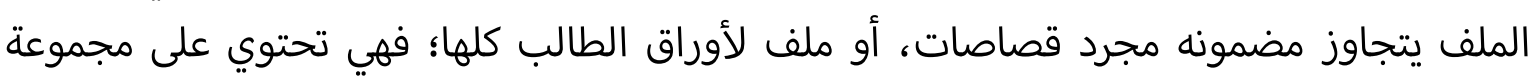

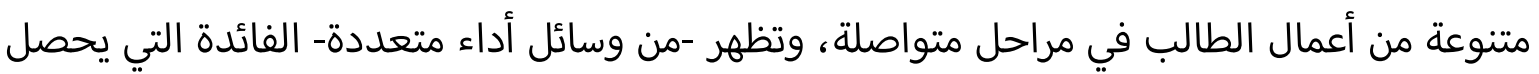
عليها (Lloyd et al., 2008, p. 190). 


$$
\text { ج) العرض الشفهي }
$$

يتضمن تنفيذ العرض الشفهي من قبل الطلاب القيام بجمع المعلومات وتنظيمها وتحليلها بهدف الوصول إلى ما يحتاجون منها لتحقيق أهداف معينة، وبعد ذلك يشكلون من العناصر المتناثرة كلًا متكاملًا، ويسجلون بعد ذلك المادة المطلوبة للعرض بأسلوب يختارونه ليتم من خلاله تقديم عمليات تعلمهم بأفضل الطرائق الممكنة، كما يتواصلون مع المستمعين أو الحضور ليوضحوا ما تعلموه

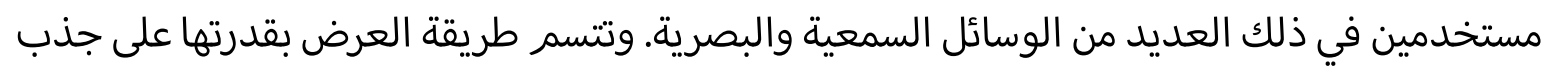
الطلاب للمادة التي تعلموها، وتمنحهم الفرصة لعرض مجال واسع من مهارات الاتصال ليتواصلوا علميًا مع الآخرين (al-Sa'dawī, 2018, p. 192).

$$
\text { د) الاختبارات التي يعدها الطالب }
$$

الطلب من الطلاب أن يقوموا بتجهيز اختبارات المقررات الدراسية تعد منهجية فاعلة وجديدة ضمن

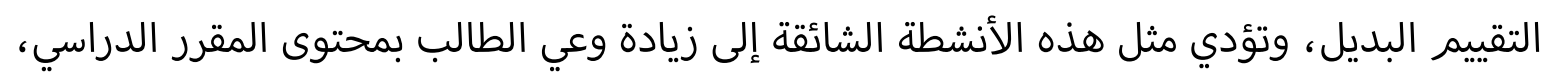
والوقوف على تفصيلاته كما تمكنه من ممارسة صيغ الأسئلة، ونماذج من استراتيجيات تناول الاختبار المحتوى التعليمي، والاختبارات التي يعدها الطلاب تعتبر تمارين تعليمية جيدة وإحدى أنشطة Lloyd et al., 2008, p. ) المراجعة تشجع الطلاب على الاشتراك في تحمل مسؤولية العملية التعليمية

o إن بعض مخرجات التعلم يمكن تحقيقها تحقيقًا أفضل من خلال تقديم الطالب لمنتج يتماشى مع طبيعة المادة، مثل: تأليف قصة أو كتابة مقال، وللمنتج فائدة كبيرة في استثارة تفكير الطلاب وتنمية قدراتهم (al-Sa'dawī, 2018, p. 201).

7) المتعلم بوصفه مرتكز التقييم التقييم الذي ينطلق من الطلاب يشرك الطلاب في مجالات كثيرة من بناء الاختبار، على سبيل المثال بإمكان الطلاب المساهمة في اختيار الموضوعات التي سيقوم الاختبار بتغطيتها، واختيار صيغة الأسئلة اللي سينبني عليها الاختبار، وأن يشاركوا في خطة توزيع الدرجات على أسئلة الاختبار، من ميزات هذه الطريقة أنها تقلل من قلق الطلاب من الاختبارات وتعطيهم حافزا أكبر للدراسة الإنبات

.(Lloyd et al., 2008, p. 191)

(V

ترتكز أهداف المشاريع على مضمون الأهداف التعليمية، وتشمل أحيانا مجموعة من الطلاب يعملون مع بعضهم ببعض بهدف جمع معلومات تتعلق بموضوع معين وخلال هذه العملية يجب على منى 
الطلاب أن يستخدموا مصادر معلومات موثوقة، ويجب عليهم أن يقيّموا المعلومات التي يحصلون

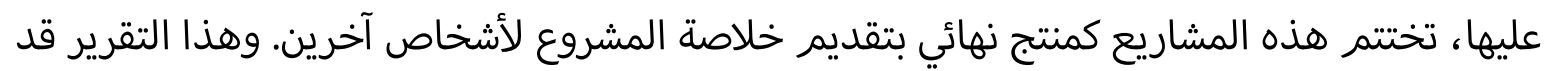

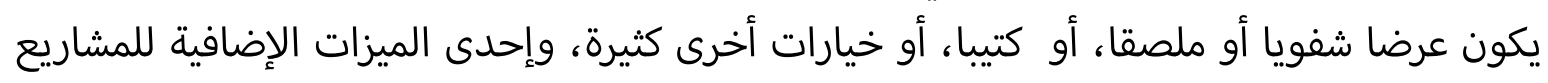
هي دمج المهارات اللغوية للطالب في سياق واقعي (Lloyd, 2008, p. 192).

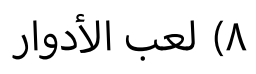

يطلب من الطالب القيام بدور معين والتفاعل مع المشاركين معه، وكذلك التواصل مع المشاهدين،

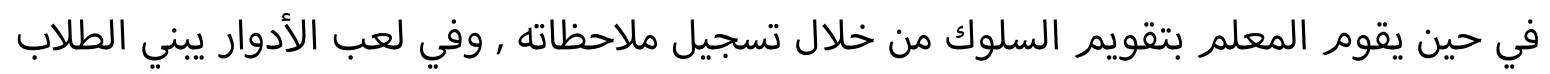

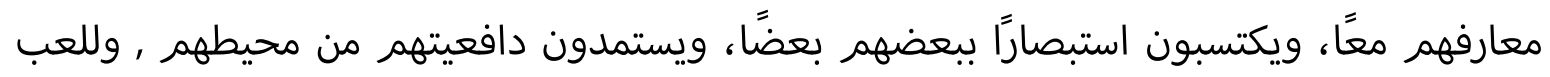
الأدوار قدرة كبيرة على إثارة حماس الطلاب (al-Sa'dawī, 2018, p. 205).

9) ( - (الأنشطة اللغوية تتنوع أنماط الأنشطة اللغوية التي تهدف إلى تنمية كفايات متعلمي اللغة العربية لغير الناطقين بها،

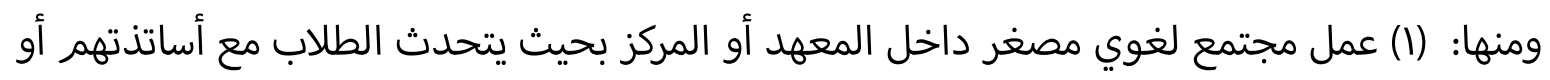

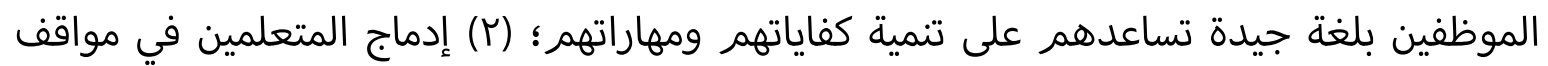

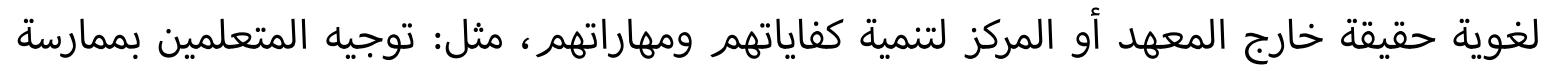

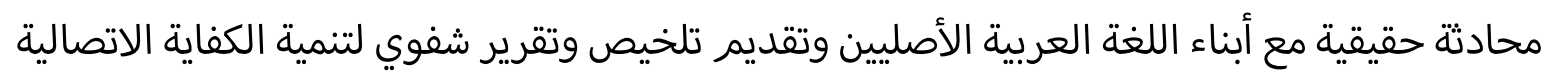

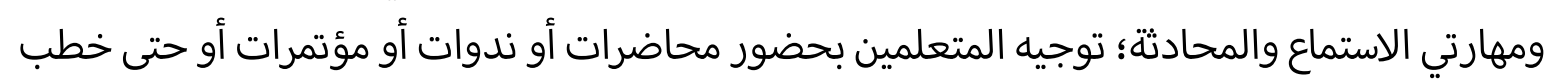
الجمعة وتقديم تلخيص وتقرير شفوي ومكتوب لتنمية الكفاية اللغوية ومهارتي الاستماع والكتابة؛

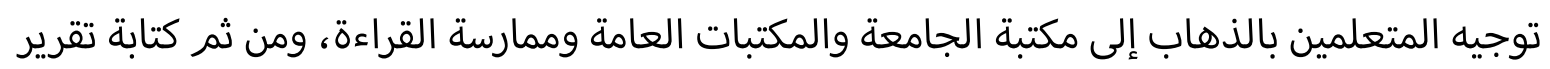

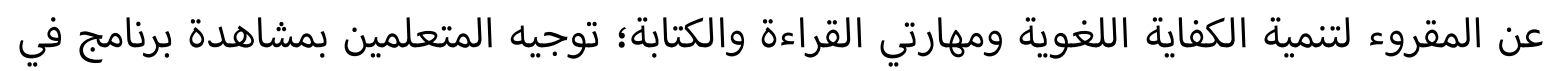

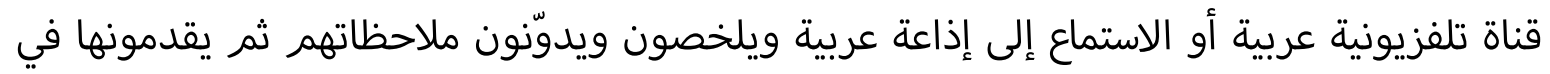

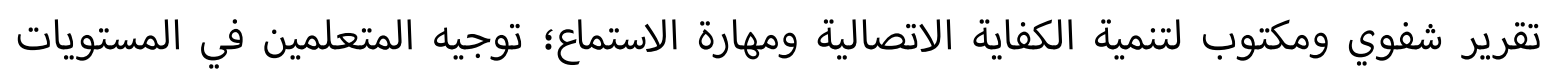

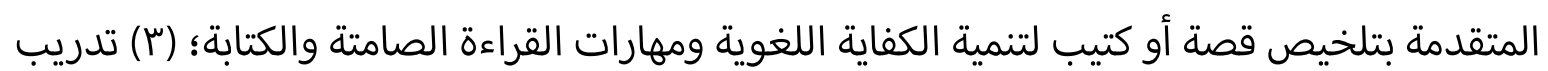

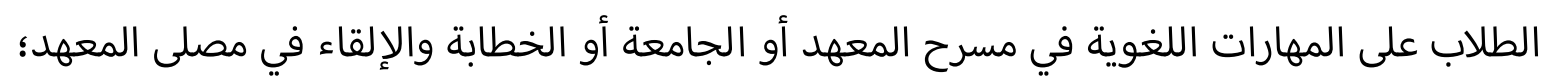

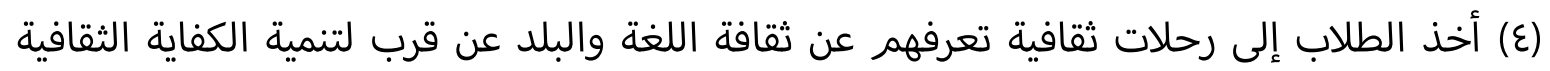
والكفاية الاتصالية؛ (0) إنشاء موقع الكتروني تفاعلي يشارك فيه الطلاب تجاربه تلإبهم ومشاعرهم ومقالاتهم وواجباتهم باللغة العربية لتنمية الكفاية اللغوية والكفاية الاتصالية. 


$$
\text { س. تقويم الكفايات عبر الاختبارات }
$$

بما أن مفهوم التقويم يشمل التطوير والتعديل والإصلاح فإن الاختبارات هي جزء من التقويم؛ وليس التقويم خاص بالاختبارات فقط كما هو المعمول في كثير من معاهد ومراكز تعليم اللغات. وترتبط

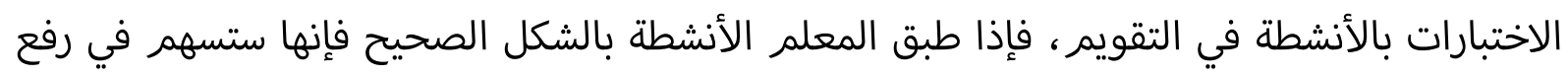
كفاءة الطالب في الكفايات الثلاث ويستطيع أن يتعامل مع الاختبارات بشكل جيد. وإذا ركز على الاختبارات

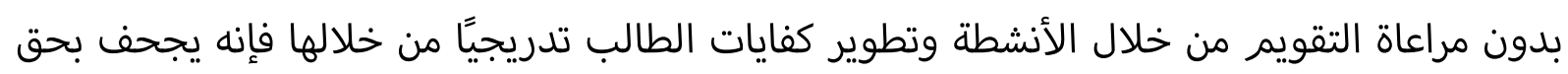
الطالب

$$
\text { ع. أنواع الاختبارات في اللغات الأجنبية }
$$

أنواع الاختبارات اللغوية، منها: (Yūnus, \& al-Shaykh, 2003, p. 298-299). أ أختبار الاستعداد

ويؤدي هذا النوع من الاختبارات وظيفة التنبؤ بمدى النجاح المحتمل الطالب في دراسة اللغة الأجنبية،

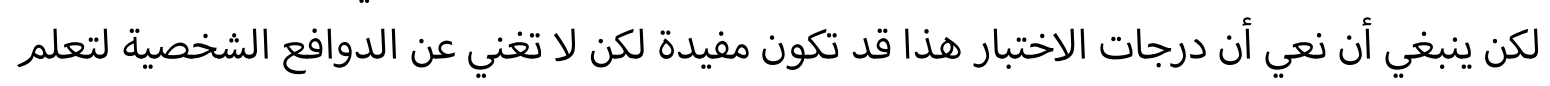
اللغة الأجنبية والتي تلعب دورا مهما في هذا المجال.

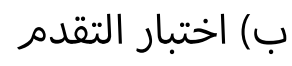

وهذا النوع من الاختبارات يقيس مدى سيطرة الطالب على المادة المقدمة في حجرة الدراسة أو في المعمل اللغوي، وبتعبير آخر يقيس مدى تقدم الطالب في اللغة الأجنبية التي يتعلمها (ا) اختبار التحصيل، وهو يقيس مدى سيطرة الطالب اللغة بصفة عامة أي أن هذه الاختبارات لا تعتمد على مقرر بعينه بل يعدها مجموعة من الممتحنين الخارجيين؛ (Y) اختبار الكفاءة، وتحدد اختبارات الكفاية مستوى تحصيل الطالب بالرجوع وبالنظر إلى مستوى دراسي معين، والممتحن في هذا الاختبار لا يهمه أن يعرف ما إذا كان الطالب قد سيطر على مهارات خاصة أو محتوى معين بل يهمه بالدرجة الأولى أن يعرف مدى قدرة الطالب على مواصلة الدراسة في مرحلة تعليمية معينة في المرحلة الجامعية.

0. أنواع الاختبارات اللغوية أنواع الاختبارات اللغوية، منها: (166-Kh (al-Khūlī, 200, pp. أ) اختبارات المفردات

وتشكل المفردات جزءًا رئيسًا في المقدرة اللغوية للطالب، وهناك عدة أنواع لاختبارات المفردات مثل: اختبار ملء الفراغ، واختبار اختيار المرادف، واختبار الكلمات والفراغات، واختبار المزاوجة، واختبار الاستعمال في جملة، واختبار الاشتقاق، وغيرها. 
وتشمل القواعد نحو اللغة وصرفها، وهناك عدة أنواع لاختبارات القواعد مثل: اختبار الاختيار من متعدد، واختبار ملء الفراغ، واختبار تعديل الصيغة، واختبار الاشتقاق، واختبار الدمج، واختبار

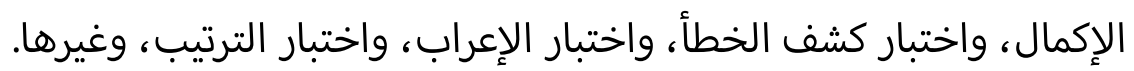
ج) اختبارات الاستماع ولاع هناك عدة أنوع لاختبارات الاستماع مثل: اختبار الكلمة المختلفة، واختبار الكلمتين المتطابقتين، واختبار الثنائيات، واختبار نوع الجملة، واختبار النص المسموع والأسئلة، واختبار النص المسموع والأسئلة، واختبار حفظ المسموع، وغيرها. د) اختبارات الكلام هناك عدة أنواع لاختبارات الكلام منها: اختبار الأسئلة عن صورة، واختبار الإعادة الشفهية، واختبار المحاورة، واختبار المقابلة الحرة، واختبار التعبير الحر، واختبار التعويض، وغيرها.

$$
\text { 0) اختبارات القراءة }
$$

هناك عدة أنواع لاختبارات القراءة منها: اختبار الاستفهام، واختبار الاختيار من متعدد، واختبار

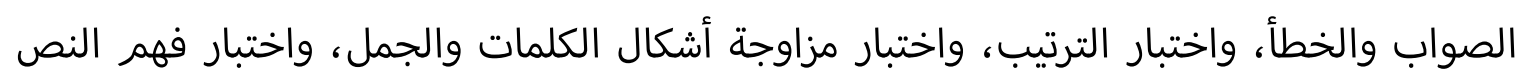

$$
\text { و) القصير، وغيرها. }
$$
وهناك عدة أنواع لاختبارات الكتابة منها: اختبار كتابة الحروف، واختبار كتابة المقاطع، واختبار المحاكاة، واختبارات الإملاء بأنواعها، واختبار الكتابة المقيدة، واختبار الإنشاء الموجه، واختبار الإنشاء الحر ،

$$
\text { واختبار التلخيص، وغيرها. }
$$

0) توزيع الدرجات لمتعلمي اللغة العربية لغير الناطقين يجب أن يختلف توزيع درجات الاختبارات لمتعلمي اللغات الثانية عن بقيّة كليات الجامعة، فتجد في كثير

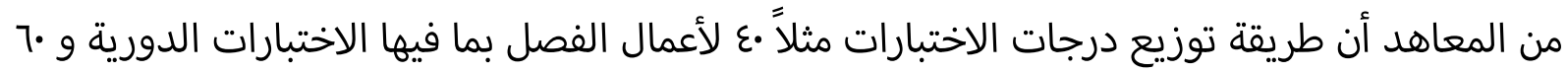
للاختبار النهائي، فعندما ندخل الطالب في منظومة التقويم هذه فإننا سندخله في منظومة تقويمية لا تسمح له بتطوير نفسه أو التمكن من الكفايات الثلاث، بل - في الغالب - سيحفظ أو يفهم عدة عدة صفئ صفحات ونماذج تدريبية قبيل الاختبار بوقت وجيز ثم يكررها في ورقة الإجابة دون أن يتمكن من الكفايات اللغوية والثقافية والاتصالية بشكل متدرج. 


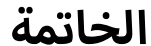

توصلت الدراسة إلى عدد من النتائج، وهي: (ا) أن هدف تعليم اللغة العربية لغير الناطقين بها هو تمكين

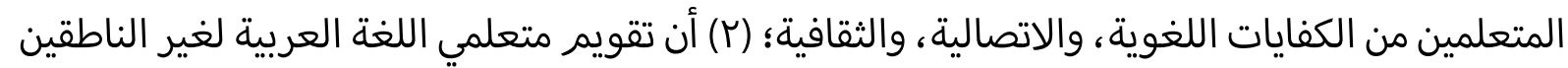

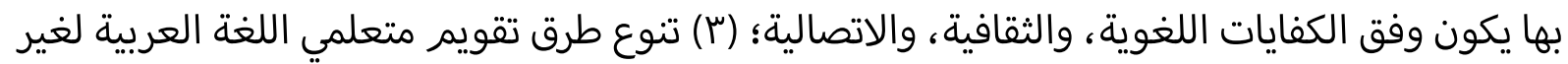
الناطقين بها بحسب الكفايات المطلوب تمكنهم منها؛ (ع) للأنشطة اللغوية دور في التقويم ، وفي تنمية

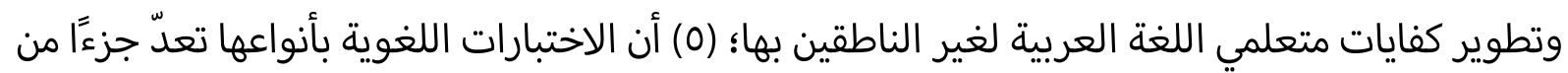
تقويم متعلمي اللغة العربية لغير الناطقين بها وليست هي طريقة التقويم الوحيدة . وتوصيات هذا الدراسة هي (ا) تكثيف البحوث والدراسات في مجال تقويم كفايات متعلمي اللغة العربية لغير الناطقين بها؛ (r) إقامة دورات تدريبية لمعلمي اللغة العربية لغير الناطقين بها بالمعاهد

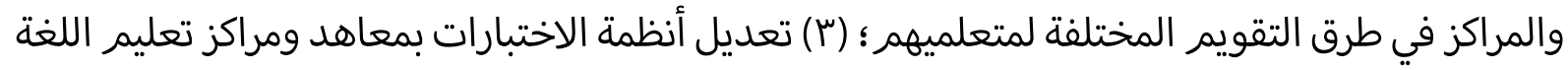

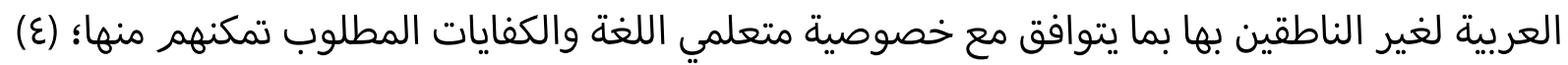
اهتمام معاهد ومراكز تعليم اللغة العربية لغير الناطق بها بالأنشطة اللغوية لتنمية الكفايات اللغوية، والاتصالية، والثقافية لدى المتعلمين.

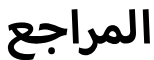

'Abd Allāh, 'A-R. Ș. (2006). al-Baḥth al-tarbawì wa-kitābat al-rasāìl al-jāmi'îyah. Amman: Maktabat al-Falāh.

'Abd Allāh, 'U. Ș. (2007). al-Usus al-nafsīyah wa-al-lughawīyah li-ta'līm al-lughāt. Majallat al'Arabìyab li-Ghayr al-Nätiqina bi-hā, 5.

al-'Așīī, 'A. I. (2001). Asāsīyāt ta'lìm al-lughah al-'Arabìyah li-al-nätịiña bi-lughāt ukbrá. Makkah: Jāmi'at Umm al-Qurá.

al-'Assāf, N. M., \& al-Wazān, Kh. M. (2014). Usus taṣmīm ikhtibārāt al-lughah al-'Arabīyah li-alnāṭiqīna bi-ghayrihā. Dirāsāt: al-'Ulūm al-Insānīyah wa-al-Ijtimā'ìyah, 41(1), 173-183.

Bānā'imah, 'Ā., (1436 H). Wathiqat binā' manhaj ta'lim al-lughah al-'Arabiyah li-ghayr alnātiqina bi-hā. Mecca: Jāmi'at Umm al-Qurá.

Brown, D. (1994). Mabādi' wa-ta 'lim al-lughah (I. H.. al-'Aqīd \& 'I. 'A. al-Shamrī, Trans.). Riyadh: Maktab al-Tarbīyah li-Duwal al-Khalīj al-'Arabī.

al-Fawzān, 'A. (2011). Iḍā'àt li-mu'allimì al-lughah al-'Arabìyah li-ghayr al-nätiqìina bi-ha. Riyadh: al-'Arabìyah li-al-Jamī'.

al-Khūlī, M. 'A. (2000). al-Ikhtibārāt al-lughawīyah. Jordan: Dār al-Falāḥ.

Lloyd, D., Davidson, P., \& Coombe, C. (2008). Asāsīyāt al-taqyìm fì al-ta lìm al-lughawì. (Kh. alDāmigh, Trans.). Riyadh: Jāmi'ah al-Malik Su'ūùd.

al-Laqānī, A. H.., \& al-Jumal, 'A. (1996). Mu'jam al-musțalaḥ̄at al-tarbawīyah fì al-manābij waturuq al-tadrīs. Cairo: 'Ālam al-Kutub. 
al-Nāqah, M. K. (1985). Khuțț muqtariḥah li-ta'lîf kitab asāsì li-ta'lim al-lughah al-'Arabiyah lial-nātiqiña bi-ghayribā. Waqā'i' al-nadawāt ta'līm al-Lughah al-'Arabīyah li-Ghayr al-Nāṭiqīna bi-hā 2. Riyadh: Maktab al-Tarbīyah al-'Arabī li-Duwal al-Khalīj.

Șāliḥ, M. I., Shu'ayb, A. 'A. 'A., al-Suḥaybānī, Ṣ., al-'Așīmī, Ṣ., al-Shamrī, 'A., al-Hudaybī, 'A. 'A. M., ... al-Shaykh 'Alī, H. H. I. (2015). 100 su'āl 'an al-lughah al-'Arabìyah. Riyadh: Markaz al-Malik ibn 'Abd Allāh ibn 'Abd al-'Azīz al-Duwalī li-Khidmat al-Lughah al-'Arabīyah.

al-Sa'dawī, 'A. b. Ș. (2018). Dalīl al-mu'allim li-al-taqwìm al-mu'tamad 'alá al-adā' min alnazarìyah ilá al-tațīq. Riyadh: Maktab al-Tarbīyah al-'Arabīyah li-Duwal al-Khalīj.

al-Shamrānī, H. b. M. (2016). Ikhtibār al-'Arabīyah al-mi'yārī: Tajribat al-Jāmi'‘t al-Su'ūdīyah alIliktrūnīyah fī qiyas al-kifāyah al-lughawīyah li-muta'allimī al-lughah al-'Arabīyah li-ghayr alnāṭiqīna bi-hā. Majallat Jāmi'at al-Malik Khālid li-al-'Ulūm al-Insānīyah, 25(1), 309-329.

al-Shuwayrikh, Ș. N. (2016). Qaḍāya asāsìyah fì ta'lìm al-lughah al-thānīyah. Riyadh: Markaz alMalik 'Abd Allāh ibn 'Abd al-'Azīz al-Duwalī li-Khidmat al-Lughah al-'Arabīyah.

Țu'aymah, R. A. (2001). Tadrìs al-'Arabìyah fì al-ta 'ìm al-'àm: Nazarìyāt wa-tajārub. Cairo: Dār al-Fikr.

Ṭu'aymah, R. A., Madkūr, A., Harīdī, A. (2010). al-Marja' fì manāhij ta'lìm al-lughah al'Arabìyab li-al-nātiqiñna bi-lughātukhrá. Cairo: Dār al-Fikr al-'Arabī.

Yūnus, F. 'A., \& al-Shaykh, M. 'A-R. (2003). al-Marja' fì ta'lim al-lughah al-'Arabiyah li-alAjānib: Min al-nazarīyah ilá al-tațbìq. Cairo: Maktabah Wahbah. 